\title{
THE HISTORICAL ASPECTS OF THE DEVELOPMENT OF THE BLACK SEA REGION
}

\author{
(c) Yulia A. Petrova, Yulia S. Shevkun \\ Rostov State University of Economics, Rostov-on-Don, Russian Federation \\ science-almanac@mail.ru
}

The Black Sea region had passed a long way of historical development even before the emergence of Greek cities. There are evidences of ancient mythology, ancient historians, toponymy and archaeological sources of these remote times, though they are still unclear in many respects. In this historical period, on the northern shores of the Black Sea, the colonists-Greeks settlements arise, in whose face the local population enters into permanent intercourse with representatives of the ancient slave society for the first time. The centuries-old history of the Greek cities of the Black Sea region, their long relationship with the Scythians and other inhabitants of the region, the complex interrelationship of two cultures different both in origin and in inner content had led to the new historical and cultural situation in our South, in the conditions of which later the East Slavic tribes and the first Russian state had been forming. The first acquaintance of the brave Aegean navigators with inhospitable shores of Pontus was reflected in the myth of the Argonautic expedition. Then the myths of Iphigenia in Taurida, Achille on the island of Levka, the stay of Odysseus in the gloomy land of the Cimmerians followed. The final link is the fantastic geography of the Logographers with legends of the Hyperboreans and the struggle of the Arimaspians with vultures. Let us try to reveal the historical reality veiled by the fantasy of myth. Let's establish the connection between the North Black Sea Region and the ancient states of the Mediterranean with the help of concrete historical evidence.

Key words: the Black Sea Region, historical development, ancient civilizations.

\section{[Ю.А. Петрова, Ю.С. Шевкун Исторические аспекты развития Черноморского региона]}

Причерноморье еще до возникновения греческих городов прошло сложный путь исторического развития. Об этих отдаленных временах имеются свидетельства античной мифологии, древних историков, топонимики и археологические источники, правда, еще во многом неясные. В этот исторический период на северных берегах Черного моря возникают поселения колонистов-греков, в лице которых местное население впервые вступает в постоянные отношения с представителями античного рабовладельческого общества. Многовековая история греческих городов Причерноморья, длительные их взаимоотношения со скифами и другими насельниками края, сложные взаимодействия двух различных и по своему происхождению, и по внутреннему содержанию культур привели в результате к новой исторической и культурной обстановке на нашем Юге, в условиях которой в последующее время шло формирование восточнославянских племен и образование первого русского государства. Первое знакомство отважных эгейских мореходов с негостеприимными берегами Понта получило отражение в мифе о походе Аргонавтов. Далее следуют мифы об Ифигении в Тавриде, об Ахилле на острове Левке, о пребывании Одиссея в мрачной стране киммерийцев. Завершающим звеном является франтастическая география Логографов со сказаниями о гипербореях и борьбе артмаспов с грифами. Постараемся же выявить историческую реальность, завуалированную фантастикой мифа. С помощью конкретных исторических свидетельств установим связь Северного Причерноморья и античных государств Средиземноморья.

Ключевые слова: Причерноморье, историческое развитие, античные цивилизации.

Yulia A. Petrova - candidate of philosophical sciences, associate professor of foreign languages for economic specialties. Rostov state university of economics. Rostov-on-Don, Russian Federation.

Петрова Юлия Андреевна - кандидат философрких наук, доцент кафедры иностранных языков для экономических специальностей. Ростовский государственный экономический университет. г. Ростов-наДону, Российская Федерация.

Yulia S. Shevkun - student. Rostov state university of economics. Rostov-on-Don, Russian Federation. Шевкун Юлия Сергеевна - студентка. Ростовский государственный экономический университет, Ростов-на-Дону, Российская Федерация. 
"The faith in the future will be found in the greatness of their past. Let civilizations pass, but people will always remember those who lived before and who created the world in which we live". (The inscription in the Museum of Anthropology in Mexico) $[1 ; 8]$.

The Northern Black Sea coast is the "quintessence" of interaction of many ancient civilizations on the territory of the northern lands of the Black Sea basin. The territory from the lower reaches of the Danube to the northern spurs of the Caucasus range has been bearing the imprint of the Greek, Roman, Scythian and Slavic peoples for several millennia, combining the unique culture of each of them.

The Greeks became the first who influenced the development of the Northern Black Sea coast. In the 8th-6th centuries BC during the Great Greek colonization they appeared on the northern shore of the Black Sea. The largest cities of that time - Tira (modern Belgorod-Dnestrovsky on the banks of the Dniester estuary), Olvia (on the right bank of the Bug-Dnieper estuary), Khersones, Feodosia, Panticapaeum (modern Kerch) were founded by settlers from Asia Minor Greece in the 6th century BC [4, p. 19]. Since the culture of Ancient Greece was characterized by a deeply secular nature and was oriented toward a free civil personality, a polis democracy that protected its rights and freedoms, and was rightfully considered the main center for the formation and development of philosophy, science, literature, art and architecture, the fact that the Greek settlers retained the political organization, way of life and customs of the metropolis, is not at all surprising [7]. Therefore, the cities of the Black Sea region were in most of the cases typical Hellenic policies with all the attributes of a democratic system. However, the usual "Greek" life of the Northern Black Sea Coast ended after large-scale confrontations of the gaining power of Rome and Hellas. As a result of these events, Greece became a part of the Roman Empire and, beginning from the 1st century BC the Romans penetrated the northern Black Sea region more and more actively, cities became politically and militarily dependent on Rome, Roman garrison was introduced into some cities, and portraits of Roman emperors were minted on coins. The Black Sea coast surrendered under the onslaught of Rome just like Hellas [2].

In the 4th century BC a large slave state, the Bosporan Kingdom, was formed in the Northern Black Sea region. Its borders covered the territory of the Kerch Peninsula, the Taman Peninsula and the lower reaches of the Don. The capital of the state was the city of Panticary. In addition to the Greeks, a significant part of the population of the Bosporus Kingdom was made up of Scythians (nobles, merchants, artisans, farmers, slaves).

In the year of $107 \mathrm{BC}$ there was an uprising of slaves here. The rebellious slaves killed the king, seized power and proclaimed their leader, Savmak, the tsar. Up to our time several silver coins with the image and inscription "King Savmak" have come down [6]. Obviously, the insurgents held power for a long time, even managed to mint coins. With great difficulty, calling on the aid of foreign troops, the Bosporan slaveholders suppressed the uprising.

While the coastal zone of the Northern Black Sea Coast was in the grip of the GreekRoman antiquity, the steppe expanses to the North of the coast were inhabited by barbarians (peoples who were on a barbaric stage), so they were called by "civilized" Greeks and Romans. But time was smoothing out the "sharp corners", and new relationships came to replace the hostility, namely: the local tribes of the Northern Black Sea (Getae, Cimmerians, Scythians, Sarmatians, Alans, Taurians, Sinds, Meots) were increasingly involved in various relationships with Greek cities, led active trade with them, fought, concluded peace treaties, established their own protectorate.

The rulers of the local tribes became residents of Greek cities, contributing their material and cultural contribution to their lives. It was in the territory of the Northern Black Sea region that cultures began to mix and penetrate each other, and as a result, the processes 
of "barbarization" of Greek cities and the "Hellenization" of surrounding tribes began to accelerate the process of their socio-economic development. It is also known the

fact that in the history of the Bosporan Kingdom, from the first centuries of the new era, kings began to wear "barbaric" names (Kotis, Reskuporid, Remetalk, Savromat, etc.). And at the same time, one Iranian-speaking people, who created in the 7-3 centuries. BC a powerful country and the largest tribal union of the Northern Black Sea region, known to us under the name "Scythians", could not fully experience the influence of the Greek-Roman civilization, since from the 3rd century BC they were gradually superseded by the Sarmatians, close to the Scythians by origin and culture [2].

The Great migration of peoples has had a tremendous impact and a crushing blow to the ethnic and political situation prevailing in the Northern Black Sea Coast. In the middle of the 3rd century Germanic tribes are ready, and since the 4th century. Huns who came from the steppes of Asia, destroyed most of the Greek cities of the Northern Black Sea region, crushed and in their progress to the west carried away the remains of Sarmatian tribes, among which Alans were especially famous. As allies of the Huns, the Alans passed through all of Europe; later Roman historians will tell about the Alan cavalry on the middle Danube and on the Rhine, in Gaul and on the British Isles, in Spain and even in Africa. Modern Ossetians are direct descendants of the Scythian-Sarmatian population of the Northern Black Sea Region [8]. However, the Gothic detachments did not have any noticeable effect on local cultural life, but, on the contrary, very soon learned the Black Sea norms of life and culture. This explains the mysterious, at first glance, fact that archaeological science, studying the development of culture in the Northern Black Sea region, cannot catch any tangible signs of the appearance of ready. During the first centuries of our era, the continuity of cultural life in the Black Sea region was not violated, and so it continued until the invasion of the Huns. According to the Latin writer of the 4th century Ammianus Marcellinus, the Huns, having crossed the Volga, first fell upon the Alans, who lived near the Sea of Azov and in the lower reaches of the Don.

After the Great Migration of Nations, it took one or two centuries for the peoples, who came into motion to settle in their new borders, laying in many respects the foundations of the ethnopolitical map of medieval Europe. At this time in the historical arena the Slavs first appeared, who later became an important ethnic and political factor in European history. Since the 6th century they widely dispersed in Central, Eastern and South-Eastern Europe, laid the foundation for the emergence of the first Slavic states.

Thus, the acquaintance with the Northern Black Sea Coast enriched the ancient science with information on the geography of South-Eastern Europe, rivers and valleys that existed there, the flora and fauna, acquainted with the countries of the colder climate. The ideas about the ethnography of the Scythians and other tribes were greatly enriched. The steppe world, especially the life of nomads, their somatic appearance, clothing, weapons, customs, and religious ideas became the property of ancient science, contributing to the acquisition of a more universal character. It should be noted that although the farmers in the Northern Black Sea region were numerically more prevalent, the Greeks were more attracted by nomads, more original in color and at the same time playing a greater political role. The ancient centers of the Northern Black Sea Coast, enriching the Hellenic world with new ideas in science, also contributed to the emergence of new images in art. This affected first of all the Bosporan rhetoric, where we find expressive scenes from the life of the North-Baltic barbarians in their characteristic surroundings, the transfer of their faces, hairstyles, clothes, weapons, images of them fighting or training horses.

In the works of ancient literature, the subject, connected with the life of the barbarians of the Northern Black Sea Coast, also played a role in the Hellenistic period and in the first centuries AD (Lucian). One of the peculiar features of ancient literature, beginning with 
Homer, and especially in the person of Efor, was the idealization of the barbarians of the Northern Black Sea region, depicted in the form of virtuous nomads living according to the laws of nature, which were opposed to the depraved population of Mediterranean cities.

So, although the largest centers of ancient culture were the Mediterranean countries, however, the North-Spanish centers also contributed to it, which gave it even more universal character [3, p. 88].

\section{Лumepamypa}

1. Кузык, Б.Н., Яковец Ю.В. Цивилизации: теория, история, диалог, будущее - пространство взаимодействия цивилизаций. М.: Институт экономических стратегий, 2008.

2. Исторические судьбы Северного Причерноморья, научная статья. URL: http://www.lants.ru/history/DRSZI/I.intro.htm .

3. Блаватский В.Д. Вопросы истории. 1960.

4. Иессен А. А. Греческая колонизация Северного Причерноморья. 1947.

5. Basilaia M.A., Zharkova M.G. Search for new ways of ecological crisis overcoming // Научный альманах стран Причерноморья. 2017. № 2.

6. Kolosova O.Y., Goncharov V.N. Positive ecological practices formation as condition for ecological crisis overcoming // Научный альманах стран Причерноморья. 2017. № 2.

7. Petrova Yu., Yarovoy M. Comparative-historical and cultural analysis of eastern Black sea region people's interaction // Научный альманах стран Причерноморья. 2017. № 3 (11).

8. FilatovaT.V. Expedition hydrochemical studies of the Black Sea coastal zones and the Kerch Strait in 2007-2008 // Научный альманах стран Причерноморья. 2017. № 3.

\section{References}

1. Kuzyk, B.N., Yakovets Yu.V. Tsivilizatsii: teoriia, istoriia, dialog, budushchee - prostranstvo vzaimodeistviia tsivilizatsii [Civilizations: theory, history, dialogue, future - the space of interaction of civilizations]. Moscow: Institute of Economic Strategies, 2008 (in Russian).

2. Historical fates of the northern Black Sea region, a scientific article. URL:http://www.lants.ru/history/DRSZI/I.intro.htm

3. Blavatsky V.D. Voprosy istorii [Questions of history] 1960 (in Russian).

4. Iessen A.A. Grecheskaia kolonizatsiia Severnogo Prichernomor'ia [Greek colonization of the Northern Black Sea coast], 1947 (in Russian).

5. Basilaia M.A., Zharkova M.G. Search for new ways of ecological crisis overcoming. Science Almanac of Black Sea Region Countries. 2017. No. 2.

6. Kolosova O.Y., Goncharov V.N. Positive ecological practices formation as condition for ecological crisis overcoming. Science Almanac of Black Sea Region Countries. 2017, № 2.

7. Petrova Yu., Yarovoy M. Comparative-historical and cultural analysis of the eastern Black sea region people's interaction. Science Almanac of Black Sea Region Countries. 2017. No. 3 (11).

8. FilatovaT.V. Expedition hydrochemical studies of the Black Sea coastal zones and the Kerch Strait in 2007-2008. Science Almanac of Black Sea Region Countries. 2017. No. 3. 